\title{
EXERCISE AND PEAK BONE MASS: RECOMMENDATION FOR BUILDING HEALTHY BONES IN CHILDREN
}

\author{
A Andi Kurniawan \\ Indonesia Sports Medicine Centre \\ Indonesian Osteoporosis Association \\ Correspondence: andi09ismc@gmail.com
}

\begin{abstract}
Regular Physical activity (PA) and exercise plays a vital role in the health and well-being of people of all ages, and its associated with positive outcomes relating to weight status, cardiometabolic markers, chronic disease prevention, bone health and mental health. Genetic factors are the strongest determinants of bone mass, but PA and exercise with loading of the bone also has a major impact on bone mass as well as on bone strength. Physical activity has been proposed as a key factor for developing healthy bones in childhood and adolescence, mainly when high-impact and weight-bearing exercise above a certain intensity and duration. It has been associated with bone accretion showing an important osteogenic effect, mainly when high-impact and weight bearing physical activity occur. Muscle mass is also a determinant of bone development. Several studies have examined the association between PA and bone health among youths.
\end{abstract}

Keyword: Physical activity, osteogenic, bone mass, bone strength 


\title{
LATIHAN FISIK DAN PUNCAK MASSA TULANG: REKOMENDASI AKTIVITAS FISIK UNTUK MEMBENTUK TULANG SEHAT PADA ANAK
}

\author{
A Andi Kurniawan \\ Indonesia Sports Medicine Centre \\ Indonesian Osteoporosis Association \\ Korespondensi: andi09ismc@gmail.com
}

\begin{abstract}
ABSTRAK
Melakukan aktivitas fisik secara teratur sangat berperan penting dalam kesehatan dan mempunyai dampak yang positif terhadap status berat badan seseorang, petanda kardiometabolik, pencegahan penyakit kronis kesehatan tulang dan kesehatan mental.Faktor genetik merupakan salah satu faktor penting terhadap massa tulang, tetapi aktivitas fisik dan latihan fisik juga berpengaruh terhadap massa tulang maupun kekuatan tulang seseorang, karena aktivitas fisik dengan intensitas tinggi dan yang bersifat pembebanan mempunyai efek osteogenik. Kekuatan otot seseorang juga merupakan faktor penting dalam pertumbuhan tulang. Beberapa penelitian menyatakan bahwa aktivitas fisik yang teratur berhubungan dengan kesehatan tulang terutama usia remaja.
\end{abstract}

Kata kunci: aktivitas fisik, osteogenik, massa tulang, kekuatan tulang 


\section{INTRODUCTION}

Regular Physical activity (PA) and exercise plays a vital role in the health and well-being of people of all ages, and its associated with positive outcomes relating to weight status, cardiometabolic markers, chronic disease prevention, bone health and mental health.1,2 For children and youth, regular participation in $P A$ is important for establishing positive behaviours that can be maintained throughout the life course. ${ }^{3}$

Low peak bone mass has been considered as a risk factor for developing osteoporosis later in life. 4,5 Genetic factors are the strongest determinants of bone mass, but PA and exercise with loading of the bone also has a major impact on bone mass as well as on bone strength. $6,7,8,9$

\section{DISSCUSSION}

\section{GLOBAL RECOMMENDATIONS ON PHYSICAL ACTIVITY FOR BONE HEALTH 5 - 17 YEARS OLD}

According to World Health Organization, to maintain a basic level of health, children and young people aged 5 to 17 need to do (1) at least 60 minutes of physical activity every day this should range from moderate activity, such as cycling and playground activities, to vigorous activity, such as running and tennis, (2) on three days a week, these activities should involve exercises for strong muscles, such as pushups, and exercises for strong bones, such as jumping and running, (3) many vigorous activities can help you build strong muscles and bones, including anything involving running and jumping, such as gymnastics, martial arts and football, (4) children and young people should reduce the time they spend sitting watching $T V$, playing computer games and travelling by car when they could walk or cycle instead. ${ }^{10}$

\section{THE ROLE OF PEAK BONE STRENGTH IN THE PRIMARY PREVENTION OF OSTEOPOROSIS}

Preventative strategies against osteoporosis can be aimed at either optimizing the peak bone mass obtained, or reducing the rate of bone loss. ${ }^{11}$ Optimization of peak bone mass during childhood and adolescence is a key determinant of adult skeletal health and it may decrease the risk of osteoporotic fractures by 50\%.12,13 Exercise has been associated with bone accretion showing an important osteogenic effect, mainly when highimpact and weight bearing physical activity occur. ${ }^{14}$ Muscle mass is also a determinant of bone development. ${ }^{15}$

The theoretical foundation for a direct effect of exercise on bone mass is based on the relationship between the intensity of pressure or strain on bone and the adaptation of bone stimulus. ${ }^{13}$ 


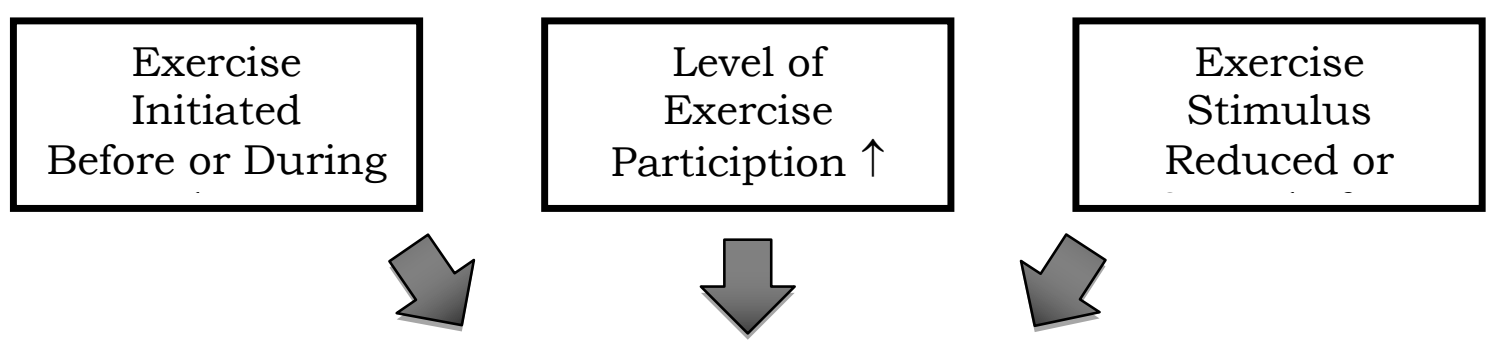

Peak Bone Mass $\uparrow$, Bone Structure Enhanced and Bone Strength $\uparrow$

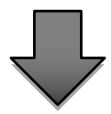

Bone Gains Preserved

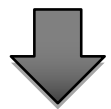

Fracture Risk $\downarrow$

Figure.1 model describing the potential role of maturity and the level of exercise participation during growth in the attainment of optimal peak bone mass, structure, and strength, and the sub-sequent effect on fracture risk. ${ }^{15}$

\section{EXERCISE DURING GROWTH HAVE A LONG-TERM EFFECT ON BONE HEALTH}

Exercise has been proposed as a key factor for developing healthy bones in childhood and adolescence, mainly when high-impact and weight-bearing exercise above a certain intensity and duration. Several studies have examined the association between PA and bone health among youths. ${ }^{14}$

\section{Sports participation and bone health}

According to their characteristics, sports can be described as osteogenic (weight-bearing exercise) and nonosteogenic (non weight-bearing exercise). Apart from numerous health benefits football, basketball and badminton is considered as an osteogenic sport both in childhood and adolescence as bone mass is augmented. 16-20 In contrast, sports such as cycling or swimming are associated with no change or a reduction in bone mass when compared to controls. $21,22,23,24,25,26,27,28,29,30,31$

Tan et al noted that of the 13 observational studies they reviewed regarding associations between organized sports participation and bone strength, all 13 showed a positive association. ${ }^{32}$ That is, young athletes had significantly greater bone strength than nonathletes across various measurement sites (proximal femur, tibia, radius, humerus, lumbar spine) and across all maturity groups.

\section{Plyometric exercise intervention to increase bone health}

Research in early puberty has shown that a novel and easily implemented 8 month Plyometric Jump Training (Bounce at the Bell; 3 min/ day) enhanced bone mass at the weight bearing proximal femur [49]. Mackelvie et al. showed that a 7 month jumping intervention (10 min, 3 times/week) was associated with more bone at the $F N$ and lumbar spine (LS) in early pubertal girls, and these results were 
maintained after 2 years. ${ }^{33,34}$ In addition, prepubertal Asian and Caucasian boys of average or low body mass index (BMI) augmented bone mineral accrual at several regions after a 7 month jumping intervention $110 \mathrm{~min}$, 3 times/week).

\section{School based physical activity intervention and bone health}

School-based study, Weeks et al randomized 99 adolescents to intervention and control groups for 8 weeks. Intervention group participants substituted 10 minutes of jumping activity for normal $P E$ warm-up activities, while the control group maintained normal $P E$ warm-up activities. Jumping activities were designed to apply high strain loads to the skeleton and included jumps, hops, squat jumps, lunges, and skipping. After 8 weeks, participants in the intervention group gained significantly more bone mass at the femoral neck, trochanter, and calcaneus than the controls. 35

School-based study, Macdonald et al randomly assigned 202 boys (aged 9-11 years) to intervention and control groups with the boys in the intervention group participating in a bone loading program not provided to the control group. ${ }^{36}$ The bone loading program consisted of 2 components: a "15 × 5" component that included 15 minutes 5 days per week of activities such as skipping, dancing, playground circuits, and resistance exercises with elastic bands and a "Bounce the Bell" component that consisted of a simple jumping activity that required students to perform either counter-movement jumps or side-to-side jumps 3 times per day, 4 days per week. Control participants engaged in normal physical education activities during two 40 minute physical education classes per week. Peripheral quantitative computed tomography showed that the 16 month intervention effectively increased bone strength of the tibia to a greater extent in the intervention group than in the control group.

\section{CONCLUSIONS}

Low peak bone mass has been considered as a risk factor for developing osteoporosis later in life. Genetic factors are the strongest determinants of bone mass, but PA and exercise with loading of the bone also has a major impact on bone mass as well as on bone strength. Optimization of peak bone mass during childhood and adolescence is a key determinant of adult skeletal health and it may decrease the risk of osteoporotic fractures by 50\%. Exercise has been associated with bone accretion showing an important osteogenic effect, mainly when high-impact and weight bearing physical activity-occur. Muscle mass is also a determinant of bone development.

\section{REFERENCES}

1. Reiner $M$, Niermann $C$, Jekauc $D$, Woll A. Long term health benefits of physical activity. A systematic review of longitudinal studies. BMC Public Health. 2013;13:813.

2. Janssen I, LeBlanc AG. Systematic review of the health benefits of physical activity and fitness in school-aged children and youth. Int $J$ Behav Nutr Phys Act. 2010;7:40.

3. Ontario Agency for Health Protection and Promotion (Public Health Ontario), Moher D, Ng B. Evidence Brief : The Positive Impact of Physical Activity on Whole Child. Toronto; 2014.

4. Rizzoli R,Bianchi $M L$, Garabedian M, McKay HA, Moreno LA. Maximizing bone mineral mass gain during growth for the prevention of fractures in the adolescents and the elderly. Bone 2010;46(2):294 - 305. 
5. Marshal $I D$, Johnell $O$, Wedel $H$. Meta-analysis of how well measures of bone mineral density predict occurrence of osteoporotic fractures. BMJ 1996;312(7041):1254-9.

6. Zofkova I. Role of genetics in prediction of osteoporosis risk. Vnitr Lek. 2011;57(1):78-84.

7. Vicente-Rodriguez G. How does exercise affect bone development during growth? Sports Med. 2006;36(7):561-9.

8. Boreham CA, McKay HA. Physical activity in childhood and bone health. $\mathrm{Br} J$ Sports Med. 201 1;45(1 1):877-9.

9. Gracia-Marco L, Moreno LA, Ortega $F B$, Leon F, Sioen I, Kafatos A, et al. Levels of physical activity that predict optimal bone mass in adolescents the HELENA study. Am $J$ Prev Med. 201 1;40(6):599-607.

10. Global Recommendations on Physical Activity for Health. World Health Organization.

11. Cummings SR, Black DM, Nevitt $M C$, et al. Bone density at various sites for prediction of hip fractures. The Study of Osteoporotic Fractures Research Group. Lancet 1993; 341(8837): 72-5.

12. Marshall D, Johnell O, Wedel H.Meta-analysis of how well measuresof bone mineral density predict occurrence of osteoporotic fractures.

$B M J$

1996; 312(7041):1254-9.

13. Vicente-Rodriguez G. How does exercise affect bone development during growth? Sports Med 2006;36(7):561-9.

14. Vicente-Rodriguez G, AraI, PerezGomezJ, Serrano-Sanchez JA, Dorado C, Calbet JA. High femoral bone mineral density accretion in prepubertal soccer players. Med Sci Sports Exerc 2004; 36(10): 1789 -95.
15. Modlesky CM, Lewis RD. Does Exercise During Growth Have a Long-Term Effect on Bone Health?. Exercise and Sport Science Reviews. 2002; 30(4):171-176.

16. Krustrup P, Dvorak J, Junge A,Bangsbo J. Executive summary: the health and fitness benefits of regular participation in small-sided football games. Scand J Med Sci Sports. 2010; 20 Suppl 1:132-5.

17. Ara I, Vicente-Rodriguez G, Perez- Gomez J, Jimenez-Ramirez $J$, Serrano-Sanchez JA, Dorado C et al.. Influence of extracurricular sport activities on body composition and physical fitness in boys: a 3- year longitudinal study. Int $J$ Obes (Lond). 2006; 30(7):1062-71.

18. Vicente-Rodriguez G, Ara I, Perez-Gomez J, Serrano-Sanchez JA, Dorado C, Calbet JA. High femoral bone mineral density accretion in prepubertal soccer players. Med Sci Sports Exerc. 2004; 36(10):1789-95.

19. Krustrup P, Hansen $P R$, Andersen LJ, Jakobsen $M D$, Sundstrup E, Randers $M B$ et al.. Long-term musculoskeletal and cardiac health effects of recreational football and running for premenopausal women. Scand J Med Sci Sports. 2010; 20 Suppl 1:58-71.

20. Calbet JA, Dorado C, DiazHerrera P, Rodriguez-Rodriguez $L P$. High femoral bone mineral content and density in male football (soccer) players. Med Sci Sports Exerc. 2001; 33(10):1682-7.

21. Nichols JF, Palmer JE, Levy SS. Low bone mineral density in highly trained male master cyclists. Osteoporos Int. 2003; 14(8):644-9.

22. Barry DW, Kohrt WM.

BMD decreases over the course of a year in competitive male cyclists. $J$ Bone Miner Res. 2008; 23(4):484-91 
23. Rector RS, Rogers $R$, Ruebel $M$, Hinton PS. Participation in road cycling $v s$ running is associated with lower bone mineral density in men. Metabolism. 2008; 57(2):226-32.

24. Olmedillas H, Gonzalez-Aguero A, Moreno LA, Casajus JA, VicenteRodriguez G. Bone related health status in adolescent cyclists. PLoS One. 2011; 6(9):e24841.

25. Olmedillas H, Gonzalez-Aguero A, Moreno LA, Casajus JA, VicenteRodriguez G. Cycling and bone health: a systematic review. BMC Med. 2012; 10:168.

26. Andreoli A, Celi M, Volpe SL, Sorge $R$, Tarantino $U$. Long-term effect of exercise on bone mineral density and body composition in postmenopausal ex-elite athletes: a retrospective study. Eur $J$ Clin Nutr. 2012; 66(1):69-74.

27. Ferry B, Lespessailles $E$, Rochcongar $P$, Duclos $M$, Courteix D. Bone health during late adolescence: effects of an 8-month training program on bone geometry in female athletes. Joint Bone Spine. 2013; 80(1):57-63.

28. Greenway KG, Walkley JW, Rich $P A$. Does long-term swimming participation have a deleterious effect on the adult female skeleton? Eur J Appl Physiol. 2012; 112(9):3217-25.

29. Ferry B, Duclos $M$, Burt L, Therre P,Le Gall F, Jaffre $C$ et al.. Bone geometry and strength adaptations to physical constraints inherent in different sports: comparison between elite female soccer players and swimmers. $J$ Bone Miner Metab. 2011; 29(3):342-51.
30. Dias Quiterio AL, Carnero EA, Baptista FM, Sardinha LB. Skeletal mass in adolescent male athletes and nonathletes: relationships with high-impact sports. J Strength Cond Res. 2011; 25(12):3439-47.

31. Tenforde AS, Fredericson $M$. Influence of sports participation on bone health in the young athlete: a review of the literature. PM $R$. 2011; 3(9):861-7.

32. Tan VP, Macdonald HM, Kim S, et al. Influence of physical activity on bone strength in children and adolescents: a systematic review and narrative synthesis. $J$ Bone Miner Res. 2014; 29: 2161-2181.

33. Mackelvie KJ, McKay HA, Khan KM, Crocker PR. A school-based exercise intervention augments bone mineral accrual in early pubertal girls. $J$ Pediatr. 2001; 139(4):501-8.

34. MacKelvie KJ, Khan KM, Petit MA,Janssen PA, McKay HA. A school- based exercise intervention elicits substantial bone health benefits: a 2-year randomized controlled trial in girls. Pediatrics. 2003; 112(6 Pt 1):e447.

35. Weeks BK, Young CM, Beck BR. Eight months of regular in-school jumping improves indices of bone strength in adolescent boys and girls: the POWER PE study. J Bone Miner Res. 2008;23: 1002-1011.

36. Macdonald HM, Cooper DM, McKay HA. Anterior-posterior bending strength at the tibial shaft increases with physical activity in boys: evidence for non-uniform geometric adaptation. Osteoporos Int. 2009;20:61-70. 